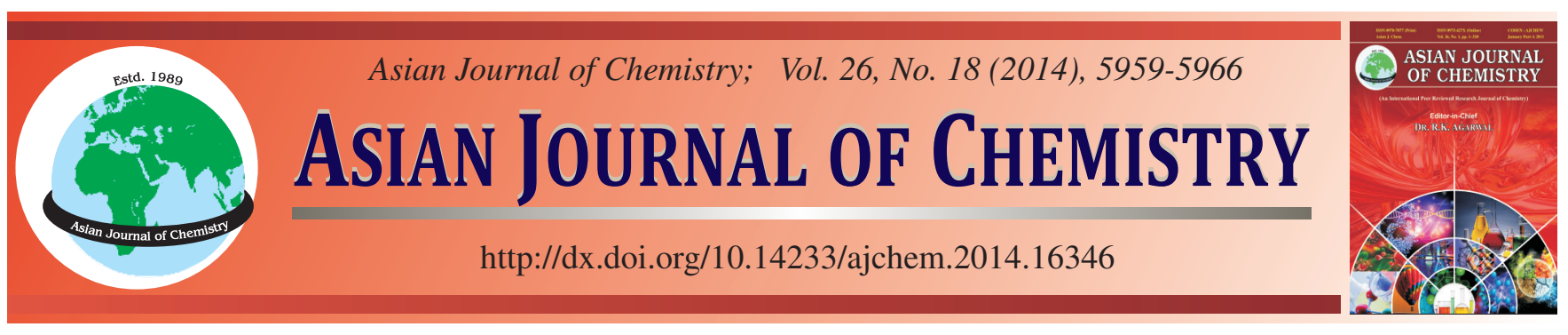

\title{
Synthesis and Photovoltaic Properties of Conjugated Copolymers Bearing bis(9,9-di(2-ethylhexyl)-9H-fluoren-2-yl)quinoxaline Subunit with Deep HOMO Level
}

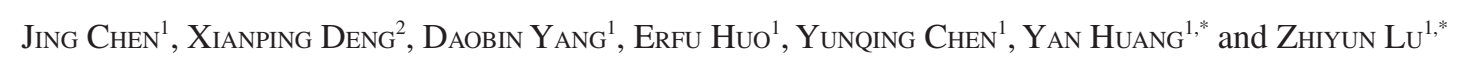

${ }^{1}$ College of Chemistry, Sichuan University, Chengdu 610064, P.R. China

${ }^{2}$ Key Laboratory of Environmentally Friendly Chemistry and Applications of Ministry of Education, College of Chemistry, Xiangtan University, Hunan 411105, P.R. China

*Corresponding authors: Tel/Fax: +86 28 85410059; E-mail: huangyan@ scu.edu.cn; luzhiyun@scu.edu.cn; hef330@aliyun.com

\begin{abstract}
A series of alternating copolymers (PT-BDFQx, PC-BDFQx and PBDT-BDFQx) have been synthesized bearing novel planar bis(9,9di(2-ethylhexyl)-9H-fluoren-2-yl)quinoxaline (BDFQx) as acceptor unit, using benzo[1,2-b:4,5-b']dithiophene (BDT), thiophene (T) and carbazole (C) as donor units via Stille or Suzuki coupling reactions. XRD characterization indicated that the presence of planar BDFQx unit (monomer 8) is favorable for the promotion of crystallization in the solid state and GPC results illustrated that the import of multiple chains in planar BDFQx unit raises the polymers molecular weight. Electrochemical measurement results suggested that three copolymers possess deep HOMO energy level of -5.50-5.77 eV. The polymer solar cell with structure of ITO/PEDOT:PSS (30 nm)/ polymer: PCBM $(60 \mathrm{~nm}) / \mathrm{B}$ phen $(10 \mathrm{~nm}) / \mathrm{Ag}(100 \mathrm{~nm})$ exhibited the highest $\mathrm{V}_{\mathrm{oc}}$ of $0.80 \mathrm{~V}$ with PBDT-BDFQx as p-type polymer, while the best power conversion efficiency (PCE) of $0.9 \%$ was obtained using a blend of PBDT-BDFQx and PCBM(1:4) as active layer.
\end{abstract}

Keywords: Conjugated polymers, Polymer solar cells, Donor-acceptor, Bulk heterojunction, Deep HOMO energy level.

\section{INTRODUCTION}

Organic/polymeric solar cells (PSCs) have been intensely explored in the past decade on account of the increasing demand of sustainable and renewable energy supply arising from rapid depletion of fossil fuels and disastrous environmental problems ${ }^{1}$. Since the seminal report by Tang ${ }^{2}$, organic/ poly-meric photovoltaic cells have made noteworthy progress. After several generations of development, the concept of bulk heterojunction (BHJ) structure solar cells is widely studied due to good performances. Up to now, the power conversion efficiencies $^{3-5}$ of BHJ-type polymeric solar cells have been enhanced over $8 \%$.

There have been some research efforts employing electrondeficient planar fused aromatic system as A subunit to construct D-A copolymer backbones which both have low HOMO energy level structure and the right energy gap, so as to enhance the open-circuit voltage of the device ${ }^{6-8}$. It is known that high $\mathrm{V}_{\text {oc }}$ is very important to improve power conversion efficiency, which is decided by the energy difference between the HOMO of the donor and the lowest unoccupied molecular orbital (LUMO) of the acceptor (such as PCBM) in BHJ polymeric solar cells ${ }^{9}$. Quinoxaline (Qx) with pyrazine ring which has power shortage shows to electron deficiency, combined with quinoxaline molecules have large flat-panel molecular structure, which improve the material carrier mobility. The most important thing is based on the receptor of copolymers, HOMO energy level of the polymer materials are relatively low and located in -5.0 -5.4 $\mathrm{eV}^{10-11}$.

In order to use of the advantages of quinoxaline unit, get lower HOMO energy level of conjugated polymer materials, we developed a novel planar electron-deficient core of bis(9,9di(2-ethylhexyl)-9H-fluoren-2-yl)quinoxaline (BDFQx) to expecting render deep HOMO polymers ${ }^{12}$. Moreover, to gain high molecular weight, fluorenes with long chains are imported to the acceptor, which expected to improve the performance of copolymers. By incorporation of different electron-donating moieties such as carbazole, thiophene and benzo[1,2- $b: 4,5-$ $b^{\prime}$ ]-dithiophene (BDT), three objective D-A copolymers with DFAQx as acceptor motif have been synthesized. All of them are found to show deep HOMO energy levels (-5.50-5.77 eV) and high number-average molecular weight.

\section{EXPERIMENTAL}

The configuration of organic photovoltaic cells is ITO/ PEDOT:PSS (25 nm)/Polymer: $\mathrm{PC}_{60} \mathrm{BM}$ (m:n, w/w, 75 nm)/LiF $(0.7 \mathrm{~nm}) / \mathrm{Al}(100 \mathrm{~nm})$. The photovoltaic cells were constructed 
with a traditional sandwich structure through the following steps. The iridium tin oxide (ITO)-coated glass substrates were cleaned by a series of ultrasonic treatments for $10 \mathrm{~min}$ in acetone, following by deionized water, then 2-propanol. The substrates were dried under a stream of nitrogen and subjected to the treatment of $\mathrm{Ar} / \mathrm{O}_{2}$ plasma for $5 \mathrm{~min}$. A filtered aqueous solution of poly(3,4-ethylenedioxy-thiophene)-poly(styrenesulfonate) (PEDOT:PSS; Bayer AG) was spun-cast onto the iridium tin oxide surface at $2000 \mathrm{rpm}$ for $30 \mathrm{~s}$ and then baked at $150{ }^{\circ} \mathrm{C}$ for $0.5 \mathrm{~h}$ to form a PEDOT:PSS thin film with a thickness of $25 \mathrm{~nm}$. A blend of copolymer and $\mathrm{PC}_{60} \mathrm{BM}$ $(1: 3 \mathrm{w} / \mathrm{w}, 20 \mathrm{mg} / \mathrm{mL}$ for polymer) was dissolved in $o$-dichlorobenzene, filtered through a $0.45 \mu \mathrm{m}$ poly (tetrafluoroethylene) filter and spun-cast at $2100 \mathrm{rpm}$ for $30 \mathrm{~s}$ onto the PEDOT:PSS layer. The substrates were dried under $\mathrm{N}_{2}$ at room temperature and then annealed at $150{ }^{\circ} \mathrm{C}$ for $15 \mathrm{~min}$ in a nitrogen-filled glove box. The devices were completed after thermal deposition of a $10 \mathrm{~nm}$ lithium fluoride and a $0.5 \mathrm{~nm}$ aluminum film as the cathode at a pressure of $6 \times 10^{-5} \mathrm{~Pa}$. The active area was $9 \mathrm{~mm}^{2}$ for each cell. The thicknesses of the spun-cast films were recorded by a profilometer (Alpha-Step 200; Tencor Instruments).

Device characterization was carried out under an AM 1.5 $\mathrm{G}$ irradiation with an intensity of $100 \mathrm{~mW} / \mathrm{cm}^{2}$ (Oriel 91160 , $300 \mathrm{~W}$ ) calibrated by a NREL-certified standard silicon cell. Current density-voltage $(\mathrm{J}-\mathrm{V})$ characteristics were measured by a computer-controlled Keithley 2602 source measurement unit in the dark. Power conversion efficiencies (PCEs) were detected under a monochromatic illumination (Oriel Cornerstone 260 1/4 m monochromator equipped with Oriel 70613NS QTH lamp) and the calibration of the incident light was performed with a monocrystalline silicon diode. All device characterizations were performed under an ambient atmosphere at room temperature.

${ }^{1} \mathrm{H}$ NMR spectra and ${ }^{13} \mathrm{C}$ NMR spectra were recorded on a Bruker AV-400 MHz spectrometer operating at $400 \mathrm{MHz}$ using deuterated chloroform as solvent. Number-average $\left(M_{n}\right)$ and weight-average $\left(\mathrm{M}_{\mathrm{w}}\right)$ molecular weights and polydispersity indices (PDI) of the polymers were determined on a PL-GPC model 210 chromatograph at $25^{\circ} \mathrm{C}$ at a flow rate of $1 \mathrm{~mL} / \mathrm{min}$ and the calibration were based on THF as an eluent and polystyrene as a standard. UV-visible absorption spectra were measured on a Shimadzu UV 2100 UV-visible spectrophotometer in $10^{-6} \mathrm{~mol} / \mathrm{L} o$-dichlorobenzene (ODCB) solutions and thin films casted from $o$-dichlorobenzene solution $(30 \mathrm{mg} / \mathrm{mL})$ at 1,000 rpm on quartz substrates. Photoluminescence spectra were measured using a Hitachi F-4500 spectrophotometer. Thermogravimetric analysis (TGA) and differential scanning calorimeter (DSC) were performed separately on Perkin-Elmer TGA Q500 and Perkin-Elmer DSC Q100 instruments under nitrogen atmosphere at a heating rate of $10{ }^{\circ} \mathrm{C} / \mathrm{min}$. Electrochemical measurements were conducted on a LK 2006 telectrochemical workstation at a scan rate of $100 \mathrm{mV} / \mathrm{s}$ using tetrabutylammonium perchlorate $(0.1 \mathrm{~mol} / \mathrm{L})$ as supporting electrolyte in acetonitrile with an $\mathrm{Ag} / \mathrm{Ag}^{+}$reference electrode and a platinum wire counter electrode. Polymer film was formed by drop-casting $1 \mathrm{~mL}$ of polymer solutions in THF (analytical reagent, $1 \mathrm{mg} / \mathrm{mL}$ ) onto the working electrode and then dried in the air. Each measurement was calibrated using a ferrocene-/ferrocenium $\left(\mathrm{Fc} / \mathrm{Fc}^{+}\right)$redox couple as internal standard. X-ray diffraction (XRD) data were generated using the Philips DX-100 sealed-tube X-ray generator (Cu target; I $=0.2 \mathrm{~nm}$ ) with power of $40 \mathrm{kV}$ and $35 \mathrm{~mA}$ and the scanning angle was every $0.2^{\circ}$ step over the range of $2-30^{\circ}$. The morphology of blend film was observed by an atomicforce microscopy (AFM) (MFP 3D Asylum Research instrument) in contact mode.

Synthesis of monomers and polymers: All the materials and reagents were commercially available and used without further purification. Toluene was distilled from sodium freshly prior to use. Catalyst $\mathrm{Pd}\left(\mathrm{PPh}_{3}\right)_{4}$ and monomer 1, 2, 3, 9, 10, 11 were synthesized according to the literature procedures ${ }^{13-17}$. The detailed synthetic routes to the intermediates as well as objective polymers are outlined in Scheme-I and II.

2-Bromo-9H- fluorene (4) ${ }^{\mathbf{1 8}}$ : In $250 \mathrm{~mL}$ round bottom flask, fluorene (9.96 g, $60 \mathrm{mmol})$ and $\mathrm{FeCl}_{3}(1.46 \mathrm{~g}, 9 \mathrm{mmol})$ dissolved in $80 \mathrm{~mL} \mathrm{DMF}$, then a solution of N-bromosuccimide (NBS) (11.74 g, $66 \mathrm{mmol})$ in $50 \mathrm{~mL}$ of DMF was added dropwise to the flask in dark. The reaction mixture was stirred for $24 \mathrm{~h}$ at room temperature. Then the mixture was washed with $5 \%$ of dilute hydrochloric acid, extracted with $\mathrm{CHCl}_{3}$ $(30 \mathrm{~mL} \times 3)$ and dried over anhydrous magnesium sulfate. After removal of solvent in the rotary evaporator, the residue was collected and purified via recrystallization with ethanol/ water ( $\mathrm{v}: \mathrm{v}=95: 5)$ and methanol successively as solvent to afford white crystal (13.2 g, $89.8 \%)$. m.p.: $98-101^{\circ} \mathrm{C}$.

2-Bromo-9,9-di(2-ethylhexyl)-9H-fluorene (5) ${ }^{18}$ : 2-Bromine fluorene (13.2 g, $54 \mathrm{mmol}), \mathrm{KI}$ (1 g, $6 \mathrm{mmol}), \mathrm{KOH}$ (13.61 g, $243 \mathrm{mmol}), 200 \mathrm{~mL}$ DMSO were added to a $500 \mathrm{~mL}$ round bottom flask and stirred for $0.5 \mathrm{~h}$, then a solution of brominated isooctane (26.9 g, $139 \mathrm{mmol}$ ) was added dropwise to the flask. The reaction mixture was stirred for $24 \mathrm{~h}$ at room temperature. Then the mixture was washed with $200 \mathrm{~mL}$ ice water, extracted with $\mathrm{CHCl}_{3}(30 \mathrm{~mL} \times 3)$ and dried over anhydrous magnesium sulfate. After removal of solvent in the rotary evaporator, the residue was collected and purified via column chromatography on silica gel with petroleum ether as eluent to afford yellow viscous liquid $(16.7 \mathrm{~g}, 66 \%)$.

2,2'-(1,2-Ethynediyl)-bis(9,9-di(2-ethylhexyl)-9Hfluorene) (6) ${ }^{18}$ : In $250 \mathrm{~mL}$ three-necked flask, 9, 9-di(2-ethyl hexyl)-2- bromide fluorene (9.8 g, $21 \mathrm{mmol}$ ) dissolved in 100 $\mathrm{mL}$ of toluene under the protection of argon atmosphere and stirred for $0.5 \mathrm{~h}$. Then catalytic amount of $\mathrm{PdCl}_{2}\left(\mathrm{PPh}_{3}\right)_{2}(0.71 \mathrm{~g}$, $1.1 \mathrm{mmol}), \mathrm{CuI}$ (0.21 g, $1.1 \mathrm{mmol}), 1,8$-di-azabicyclo [5.4.0] eleven carbon-7-ene (DBU) (15.98 g, $105 \mathrm{mmol}$ ), ethynyltrimethylsilane (3.08 g, $31.5 \mathrm{mmol}$ ) and diisopropylamine (12.74 $\mathrm{g}, 105 \mathrm{mmol}$ ) were added to the flask under room temperature and stirred for $1 \mathrm{~h}$. Then $10 \mathrm{~mL}$ of benzene was injected into the flask with a syringe at $80{ }^{\circ} \mathrm{C}$ for $10 \mathrm{~h}$ in dark. The mixture was poured into the saturated ammonium chloride solution, stirred for $0.5 \mathrm{~h}$, extracted with $\mathrm{CH}_{2} \mathrm{Cl}_{2}(30 \mathrm{~mL} \times 3)$ and dried over anhydrous magnesium sulfate. After removal of solvent in the rotary evaporator, the residue was collected and purified via column chromatography on silica gel with petroleum ether as eluent to afford white solid $(10.9 \mathrm{~g}, 53 \%)$. ${ }^{1} \mathrm{H} \mathrm{NMR}\left(\mathrm{CDCl}_{3}\right.$, $400 \mathrm{MHz}, \delta$-ppm): 7.64-7.61 (m, 4H), 7.56-7.47 (m, 4H), 7.33$7.26(\mathrm{~m}, 6 \mathrm{H}), 1.99(\mathrm{t}, J=8 \mathrm{~Hz}, 8 \mathrm{H}), 1.21-1.18(\mathrm{~m}, 4 \mathrm{H}), 1.10-$ $1.00(\mathrm{~m}, 36 \mathrm{H}), 0.83-0.60(\mathrm{~m}, 20 \mathrm{H})$. 
Bis(9,9-di(2-ethylhexyl)-9H-fluoren-2-yl)-1,2-ethanedione (7) ${ }^{\mathbf{1 8}}$ : Intermediate $6(3.35 \mathrm{~g}, 4.5 \mathrm{mmol}), \mathrm{I}_{2}(0.57 \mathrm{~g}, 2.3$ $\mathrm{mmol}$ ) and $25 \mathrm{~mL}$ DMSO was mixed in a flask in argon atmosphere at $155^{\circ} \mathrm{C}$ for $12 \mathrm{~h}$. Then the reaction mixture was cooled to room temperature, added to sodium sulfite solution $(25 \mathrm{~mL}, \mathrm{w}=4 \%)$ and stirred for $0.5 \mathrm{~h}$. The mixture was poured into some water, extracted with $\mathrm{CH}_{2} \mathrm{Cl}_{2}(30 \mathrm{~mL} \times 3)$ and dried over anhydrous magnesium sulfate. After removal of solvent in the rotary evaporator, the residue was collected and purified via recrystallization with ethanol as solvent to afford yellow solid (2.44 g, $65 \%)$. ${ }^{1} \mathrm{H} \mathrm{NMR}\left(\mathrm{CDCl}_{3}, 400 \mathrm{MHz}, \delta\right.$ ppm): 8.09 (s, 2H), $7.91(\mathrm{~d}, J=8.8 \mathrm{~Hz}, 2 \mathrm{H}), 7.76(\mathrm{~m}, 4 \mathrm{H})$, 7.42-7.36 (m, 6H), $2.02(\mathrm{~m}, 8 \mathrm{H}), 1.26(\mathrm{~m}, 4 \mathrm{H}), 0.89-0.49$ (m, $56 \mathrm{H})$.

5,8-Dibromo-2, 3-di(9, 9-di (2-ethylhexyl)-9H-fluoren2-yl) quinoxaline $(\mathbf{8})^{18}$ : In $100 \mathrm{~mL}$ two-necked flask, $30 \mathrm{~mL}$ glacial acetic acid was poured into it and deoxidized in argon atmosphere for $0.5 \mathrm{~h}$, then intermediates $7(1.25 \mathrm{~g}, 1.5 \mathrm{mmol})$ and $3(0.3 \mathrm{~g}, 1.8 \mathrm{mmol})$ was added to the flask. The mixture reacted at $110^{\circ} \mathrm{C}$ for $4 \mathrm{~h}$ in argon atmosphere. After the reaction, acetic acid was steamed to. The residue was collected and purified via column chromatography on silica gel with petroleum ether/ $\mathrm{CH}_{2} \mathrm{Cl}_{2}(\mathrm{~V}: \mathrm{V}=5: 1)$ as eluent to afford yellow solid (1.17 g, $73 \%) .{ }^{1} \mathrm{H} \mathrm{NMR}\left(\mathrm{CDCl}_{3}, 400 \mathrm{MHz}, \delta\right.$-ppm): 8.20 (br, 2H), 7.89 (s, 2H), $7.65(\mathrm{~m}, 2 \mathrm{H}), 7.45(\mathrm{br}, 4 \mathrm{H}), 7.31-7.25(\mathrm{~m}, 6 \mathrm{H})$, 2.17-2.03 (m, 8H), 1.03-0.78 (m, 24H), 0.83-0.78 (m, 8H), 0.70-0.54 (m, 28H). ${ }^{13} \mathrm{C} \mathrm{NMR}\left(\mathrm{CDCl}_{3}, 100 \mathrm{MHz}, \mathrm{ppm}\right)$ : $154.58,151.23,151.14,142.77,140.51,139.31,136.48$, $132.71,130.79,129.46,127.09,126.87,125.98,124.21$, $123.79,120.13,118.75,55.24,44.83,34.01,28.31,27.09$, $26.57,22.87,22.72,14.05$.

General procedure for Suzuki cross coupling polymerization: $0.675 \mathrm{mmol}$ monomer $\mathbf{7}, 0.675 \mathrm{mmol}$ monomer 11, $20 \mathrm{~mL}$ of degassed toluene, $20 \mathrm{~mL}$ of $2 \mathrm{M}$ aqueous potassium carbonate and catalytic amount of $\mathrm{Pd}\left(\mathrm{PPh}_{3}\right)_{4}$ were placed in a flask in argon atmosphere, then stirred vigorously at $100{ }^{\circ} \mathrm{C}$ for $72 \mathrm{~h}$. Then $1 \mathrm{~g}$ bromobenzene and $1 \mathrm{~g}$ phenylboric acid were added to the flask successively in argon atmosphere and then stirred vigorously at $100{ }^{\circ} \mathrm{C}$ for $12 \mathrm{~h}$, respectively. After the reactant was cooled down to room temperature, $100 \mathrm{~mL}$ $\mathrm{CHCl}_{3}$ was added. The organic layer was separated, washed with water $(3 \times 50 \mathrm{~mL})$ and dried over anhydrous $\mathrm{MgSO}_{4}$. After removal of solvent under vacuum, the resulted sticky residue was poured into methanol $(300 \mathrm{~mL})$. The precipitate was filtered, washed with methanol and redissolved in $\mathrm{CHCl}_{3}$ $(50 \mathrm{~mL})$, followed by precipitation from methanol for three times. The resulted precipitate was collected and dried under vacuum.

PC-BDFQx: Yellow solid. Yield: $88 \% .{ }^{1} \mathrm{H} \mathrm{NMR}\left(\mathrm{CDCl}_{3}\right.$, $400 \mathrm{MHz}, \delta$-ppm): 8.31 (br, 4H), 8.02 (br, 2H), 7.56-7.42 (m, $6 \mathrm{H}), 7.16$ (br, 10H), 4.28 (br, 2H), 2.22-1.26 (m, 29H), 0.990.37 (m, 54H). ${ }^{13} \mathrm{C} \mathrm{NMR}\left(\mathrm{CDCl}_{3}, 100 \mathrm{MHz}, \delta\right.$-ppm): 150.21, $149.79,149.83,140.62,140.27,139.85,138.80,138.70$, $137.71,136.74,136.56,128.47,128.24,128.17,126.90$, $125.56,125.35,124.56,124.44,123.98,123.08,122.97$, 122.20, 118.69, 117.20, 116.99, 107.60, 107.40, 53.95, 32.91, $30.90,32.92,30.91,29.96,28.67,27.85,27.01,25.73,25.5$, $23.37,22.19,21.67,21.10,13.15,9.88,9.30$.
General procedure for Stille cross coupling polymerization: $0.606 \mathrm{mmol}$ monomer $\mathbf{8}, 0.606 \mathrm{mmol}$ monomer 12, $25 \mathrm{~mL}$ of degassed toluene and catalytic amount of $\mathrm{Pd}_{2}(\mathrm{dba})_{3}$ and $\mathrm{P}(\mathrm{o}-\mathrm{Tol})_{3}$ were placed in a flask in argon atmosphere, then stirred vigorously at $100{ }^{\circ} \mathrm{C}$ for $72 \mathrm{~h}$. Then $1 \mathrm{~g}$ bromobenzene was added to the flask in argon atmosphere and then stirred vigorously at $100{ }^{\circ} \mathrm{C}$ for $12 \mathrm{~h}$. After the reactant was cooled down to room temperature, $100 \mathrm{~mL} \mathrm{CHCl}_{3}$ was added. The organic layer was separated, washed with water $(3 \times 50 \mathrm{~mL})$ and dried over anhydrous $\mathrm{MgSO}_{4}$. After removal of solvent under vacuum, the resulted sticky residue was poured into methanol $(300 \mathrm{~mL})$. The precipitate was filtered, washed with methanol and redissolved in $\mathrm{CHCl}_{3}(50 \mathrm{~mL})$, followed by precipitation from methanol for three times. The resulted precipitate was collected and dried under vacuum.

PT-BDFQx: Amaranth solid. Yield: 86.6\%. ${ }^{1} \mathrm{H}$ NMR $\left(\mathrm{CDCl}_{3}, 400 \mathrm{MHz}, \delta\right.$-ppm): 8.38-8.01 (m, 6H), 7.66-7.52 (m, $6 \mathrm{H}), 7.38-7.29(\mathrm{~m}, 6 \mathrm{H}), 2.06(\mathrm{br}, 8 \mathrm{H}), 0.90-0.70(\mathrm{~m}, 40 \mathrm{H})$, 0.52 (br, 20H). ${ }^{13} \mathrm{C} \mathrm{NMR}\left(\mathrm{CDCl}_{3}, 100 \mathrm{MHz}, \delta\right.$-ppm): 151.07 , $150.23,149.84,141.21,139.67,136.81,136.47,130.82$, $128.86,127.35,127.19,126.66,126.43,125.78,124.75$, $123.19,119.04,117.92,54.10,44.00,33.64,32.33,27.11$, 25.50, 21.71, 13.02, 9.46.

PBDT-BDFQx: Atropurpuerus solid. Yield: $87.5 \% .{ }^{1} \mathrm{H}$ NMR $\left(\mathrm{CDCl}_{3}, 400 \mathrm{MHz}, \delta\right.$-ppm): 8.39-8.17 (m, 6H), 7.92$7.54(\mathrm{~m}, 6 \mathrm{H}), 7.42-7.31(\mathrm{~m}, 6 \mathrm{H}), 4.44-4.31$ (m, 4H), 2.09$1.66(\mathrm{~m}, 18 \mathrm{H}), 1.55-1.26(\mathrm{~m}, 18 \mathrm{H}), 1.10-0.50(\mathrm{~m}, 62 \mathrm{H}) .{ }^{13} \mathrm{C}$ NMR $\left(\mathrm{CDCl}_{3}, 100 \mathrm{MHz}, \delta\right.$-ppm): 151.27, 150.21, 149.98, $143.73,141.41,139.69,138.30,136.69,136.30,132.07$, $131.21,130.78,128.85,128.75,128.68,128.64,128.61$, $127.54,127.45,125.82,124.84,123.26,119.76,119.00$, $119.00,118.33,54.17,43.76,39.76,33.50,32.32,29.43$, $28.68,28.22,27.02,25.89,25.42,22.86,22.28,21.74,13.18$, $13.01,10.28$.

\section{RESULTS AND DISCUSSION}

The general synthetic routes to the monomers and polymers are illustrated in Scheme-I and II. The conjugated copolymers PBDT-BDFQx and PT-BDFQx bearing BDFQx as subunit were synthesized via stille polycondensation reaction with BDT and thiophene as electron-donating subunit, while the conjugated copolymer PC-BDFQx was synthesized via Suzuki polycondensation reaction with carbazole as electron-donating subunit. The three copolymers possess excellent solubility in common organic solvents such as THF, chloroform, toluene and chlorobenzene. The molecular structures of the monomers and polymers have been confirmed by ${ }^{1} \mathrm{H}$ NMR. Molecular weight of the polymers was determined by gel permeation chromatography (GPC) using THF as the eluent and polystyrenes as the standards at room temperature. The results (vide Table-1.) indicate that number-average molecular weight $\left(\mathrm{M}_{\mathrm{n}}\right)$ of PC-BDFQx, PT-BDFQx and PBDTBDFQx were found to be $10.6,7.8$ and $8.1 \mathrm{kDa}$, with the corresponding polydisperisty indices of 1.91, 1.63 and 1.93, respectively (Table-1).

Thermal stability: Thermal properties of the copolymers were determined via thermogravimetric analysis in nitrogen atmosphere. As shown in Table-1 and Fig. 1, the $5 \%$ weight- 


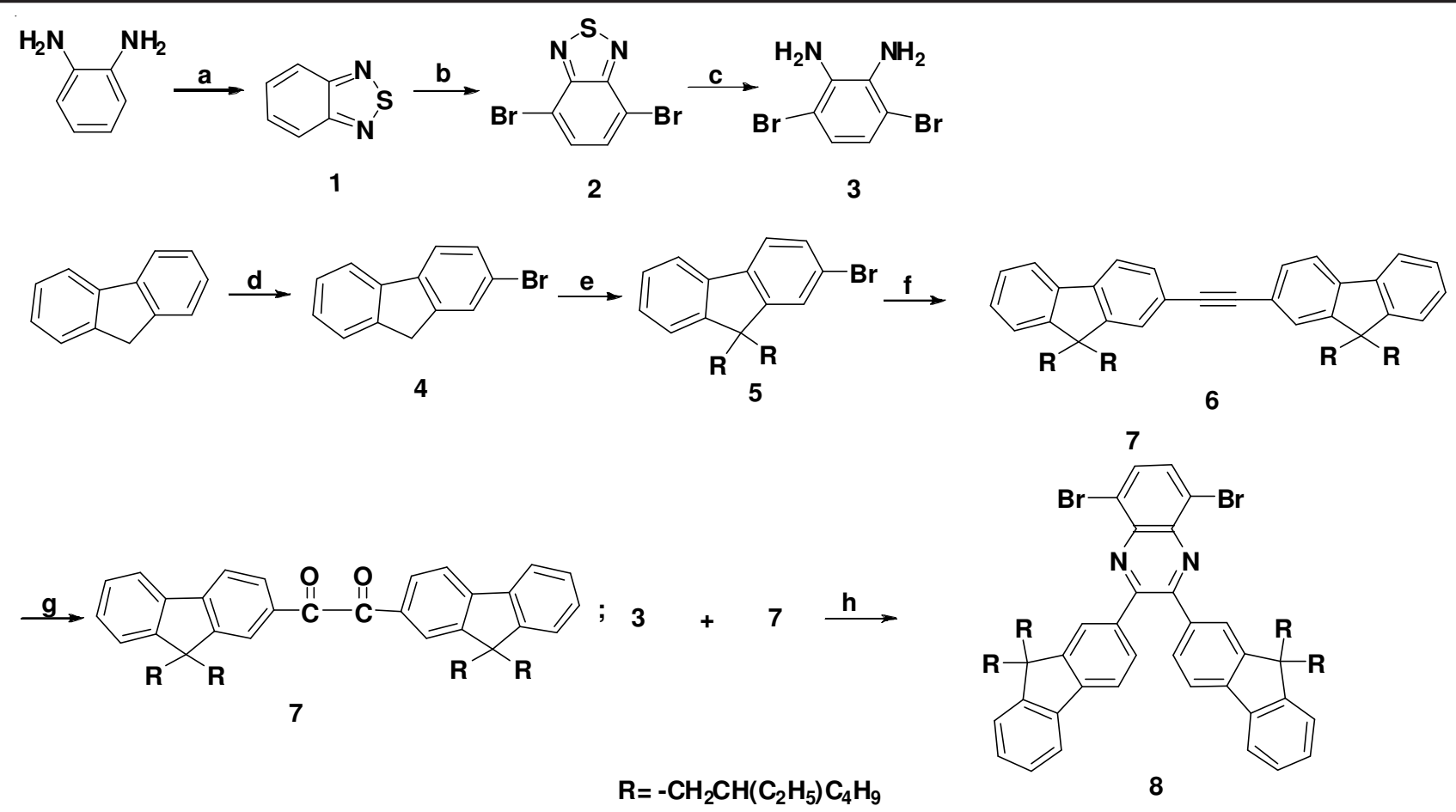

Conditions: (a) $\mathrm{SOCl}_{2}, \mathrm{Et}_{3} \mathrm{~N}$; (b) $\mathrm{Br}_{2}, \mathrm{HBr}\left(40 \%\right.$ ), reflux; (c) $\mathrm{NaBH}_{4}, \mathrm{EtOH}, 0{ }^{\circ} \mathrm{C}$; (d) DMF, NBS;

(e) $\mathrm{n}_{-} \mathrm{C}_{8} \mathrm{H}_{17} \mathrm{Br}, \mathrm{KI}, \mathrm{KOH}, \mathrm{DMSO}$; (f) TMSA, $\mathrm{Pd}(\mathrm{PPh})_{3} \mathrm{Cl}_{2}, \mathrm{CuI}, \mathrm{DBU}, \mathrm{i}-\mathrm{Pr}_{2} \mathrm{NH}$, Benzene; (g) $\mathrm{I}_{2}$,

DMSO; (h) $\mathrm{CH}_{3} \mathrm{COOH}, 120{ }^{\circ} \mathrm{C}$.

Scheme-I: Synthetic route to the intermediates

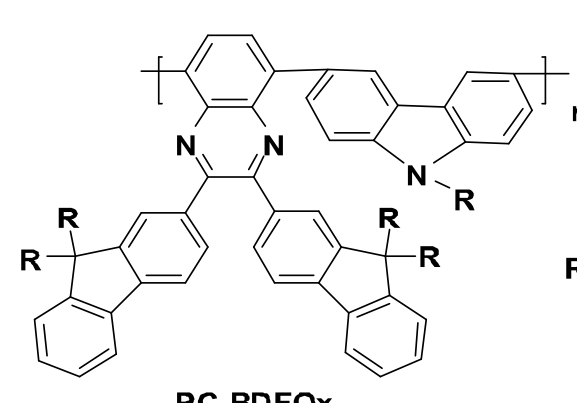

PC-BDFQX

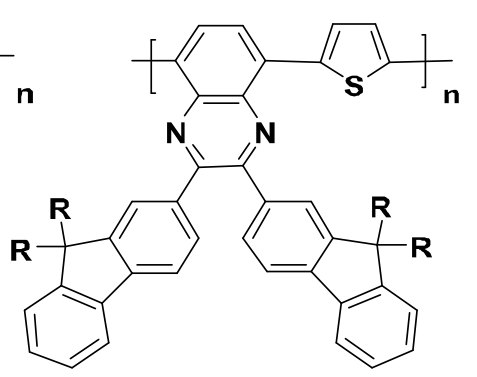

PT-BDFQx

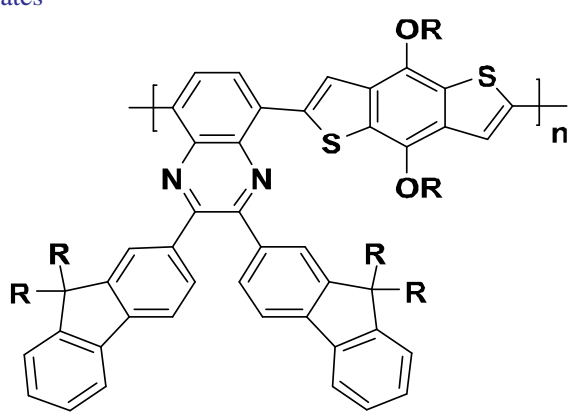

PBDT-BDFQx

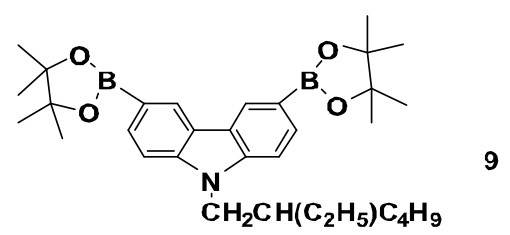

PC-BDFQx

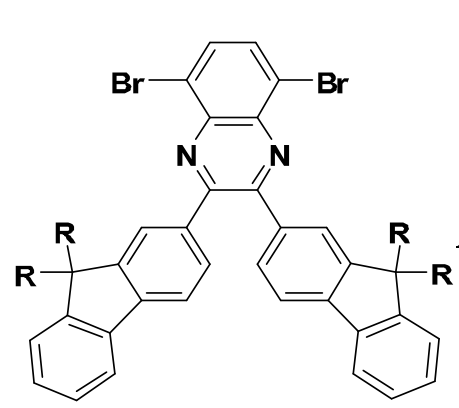

$\mathbf{P d}\left(\mathrm{PPh}_{3}\right)_{4}$

Toluene

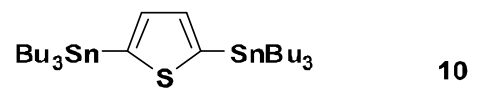

PT-BDFQx

$\mathrm{Pd}_{2}(\mathrm{dba})_{3} / \mathrm{P}(\mathrm{o}-\mathrm{Tol})_{3} \quad$ Toluene

$\left(\mathrm{H}_{3} \mathrm{C}\right)_{3} \mathrm{Sn}$

PBDT-BDFQx

$R=-\mathrm{CH}_{2} \mathrm{CH}\left(\mathrm{C}_{2} \mathrm{H}_{5}\right) \mathrm{C}_{4} \mathrm{H}_{9}$

$\mathrm{Pd}_{2}(\mathrm{dba})_{3} / \mathrm{P}(\mathrm{o}-\mathrm{Tol})_{3}$

Toluene

Scheme-II: Synthetic route to three polymers 


\begin{tabular}{ccccc}
\hline \multicolumn{5}{c}{ TABLE-1 } \\
MOLECULAR WEIGHTS AND THERMAL \\
PROPERTIES OF COPOLYMERS \\
\hline Polymer & $\mathrm{M}_{\mathrm{w}}(\mathrm{kDa})$ & $\mathrm{M}_{\mathrm{n}}(\mathrm{kDa})$ & PDI & $\mathrm{T}_{\mathrm{d}}\left({ }^{\circ} \mathrm{C}\right)$ \\
\hline PC-BDFQx & 20.3 & 10.6 & 1.91 & 373 \\
PT-BDFQx & 12.7 & 7.8 & 1.63 & 371 \\
PBDT-BDFQx & 15.6 & 8.1 & 1.93 & 326 \\
\hline
\end{tabular}

loss temperatures for PC-BDFQx, PT-BDFQx and PBDTBDFQx are in the range of $326-373^{\circ} \mathrm{C}$ and most of the polymers show good thermostability which is adequate for application of the copolymers as active materials in the optoelectronic devices.

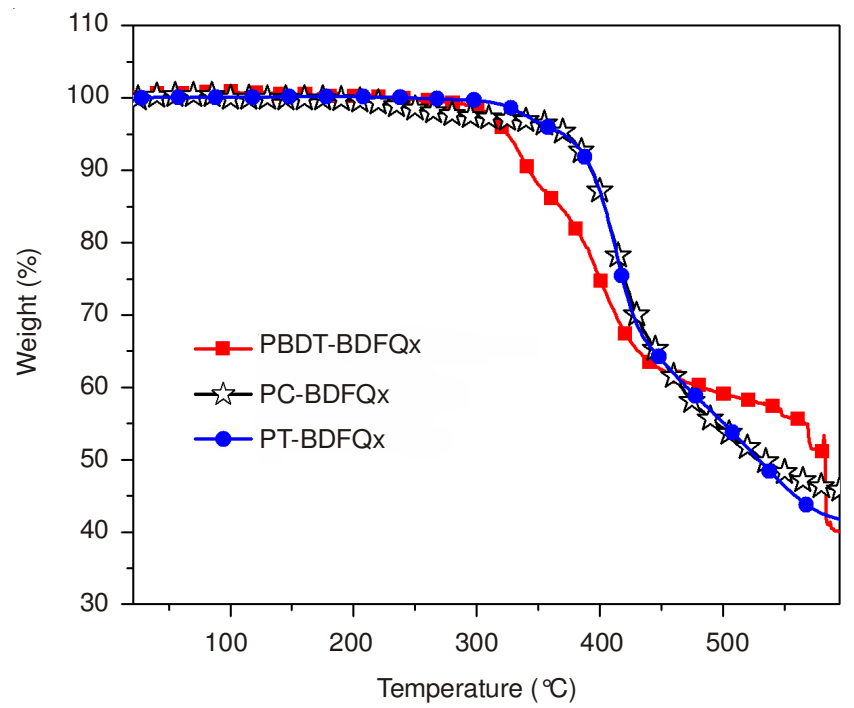

Fig. 1. TGA plots of three polymers with a heating rate of $10{ }^{\circ} \mathrm{C} \mathrm{min}^{-1}$ in nitrogen atmosphere

Optical properties: The absorption spectra of the polymers in dilute $\mathrm{CHCl}_{3}$ solution $\left(10^{-6} \mathrm{~mol} / \mathrm{L}\right)$ and in the solid films are shown in Figs. 2 and 3 and the corresponding data are summarized in Table-1. In the polymer solutions, to the polymers of PT-BDFQx and PBDT-BDFQx, two intense absorption bands could be discernable, which could be assigned to the $\pi-\pi^{*}$ transition of BDFQx moiety $(300-420 \mathrm{~nm})$ and the intramolecular charge transfer (ICT) interactions between the polymer backbone and the pendant acceptor groups transition of the polymers (430-650 nm), respectively. As for polymer PC-BDFQx, its absorption redshift only around $50 \mathrm{~nm}$ than the monomer BDFQx, which indicated that forming polymer did not increase the conjugate degree more. The reason may be due to carbazole unit containing weaker electron-donating ability, makes the polymer conjugate degree decreases. While in solid films, all three polymers absorption spectra aren't observed to red-shift, indicating the presence of unconspicuous $\pi-\pi^{*}$ stacking between the polymeric chains in solid state ${ }^{19}$, which might be attributed to the long chain structure of difluorene-substituted BDFQx unit. Additionally, from the onset absorption wavelength of the spectra in films, the corresponding optical band gap ${ }^{20}$ of $2.58 \mathrm{eV}$ for PC-BDFQx, 1.99 $\mathrm{eV}$ for PT-BDFQx and $1.97 \mathrm{eV}$ for PBDT-BDFQx could be estimated and data are summarized in Table-2.

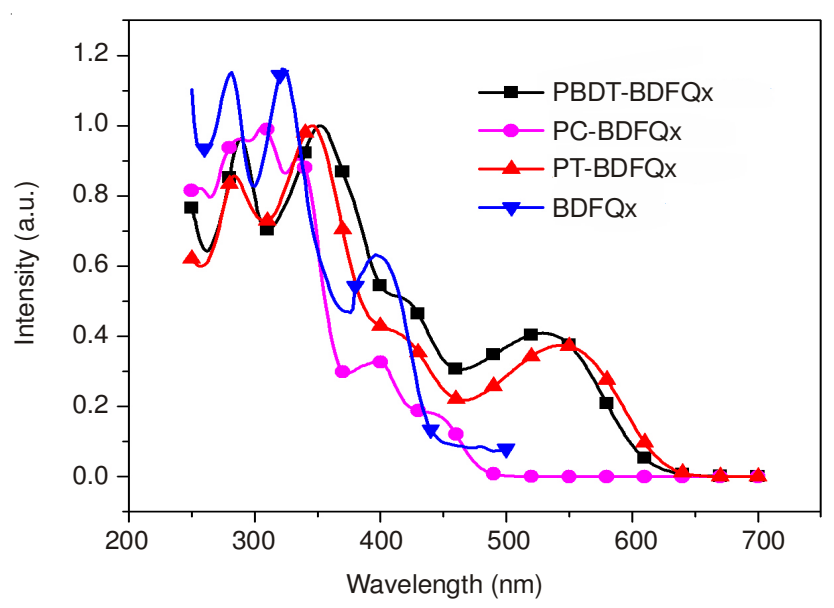

Fig. 2. Normalized absorption spectra of monomer BDFQx and three polymers in chlorobenzene solution

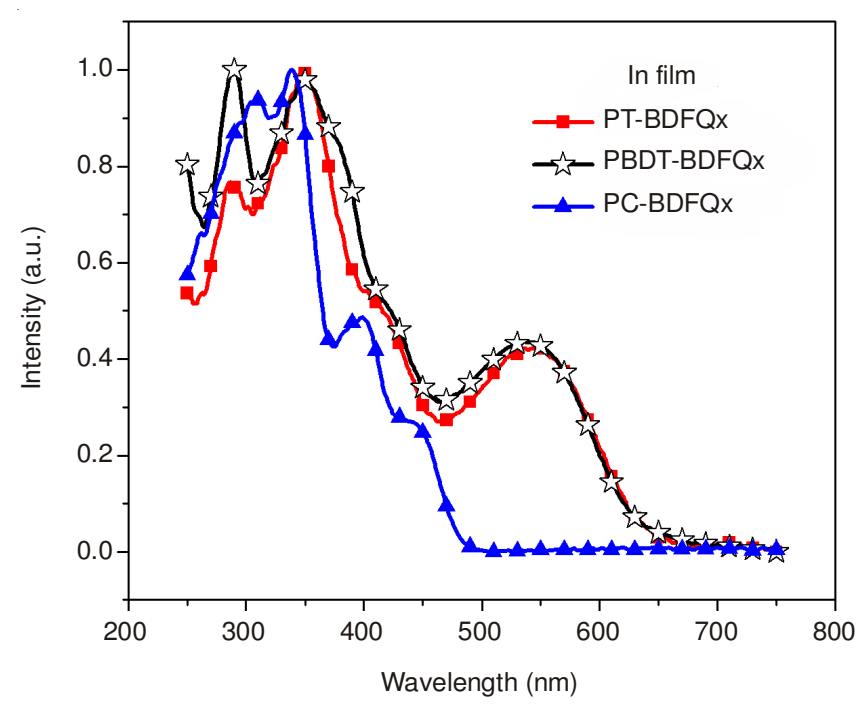

Fig. 3. Normalized absorption spectra of three polymers in film state

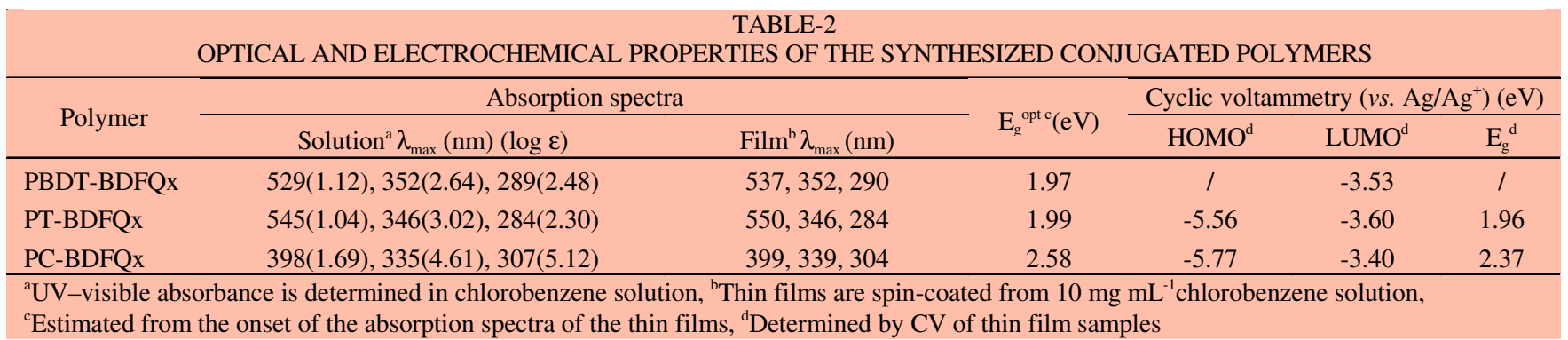


Structural properties: In order to gain the $\pi-\pi$ accumulation effect between polymer molecules and the formation of the crystallite, the molecular organization of the copolymers is examined by grazing incidence X-ray diffractometry (GIXRD). As shown in Fig. 4, two main diffraction peaks around $12^{\circ}$ and $22^{\circ}$ could be observed in both the two polymeric samples. The broad peaks at $22^{\circ}(\mathrm{d} \approx 3.9 \AA)$ may originate from the face-to-face ( $\pi-\pi$ stacking) packing signal of the aromatic groups in the main chain ${ }^{21}$, especially that arises from the packing of fused planar BDFQx block. The weak diffraction peak around at $12^{\circ}(\mathrm{d} \approx 8.6 \AA)$ probably comes from the accumulation between fluorene units in the polymer monomer. Hence, the presence of relative intense signals at $22^{\circ}$ in all the three polymer films implies the existence of closely packed polymer chains in condensed state, which is good for the enhancement of carrier mobility ${ }^{22}$. Moreover, PB exhibits the strongest signal at $22^{\circ}$ in all three polymers, which should be attributed to its larger planar BDT donar subunits.

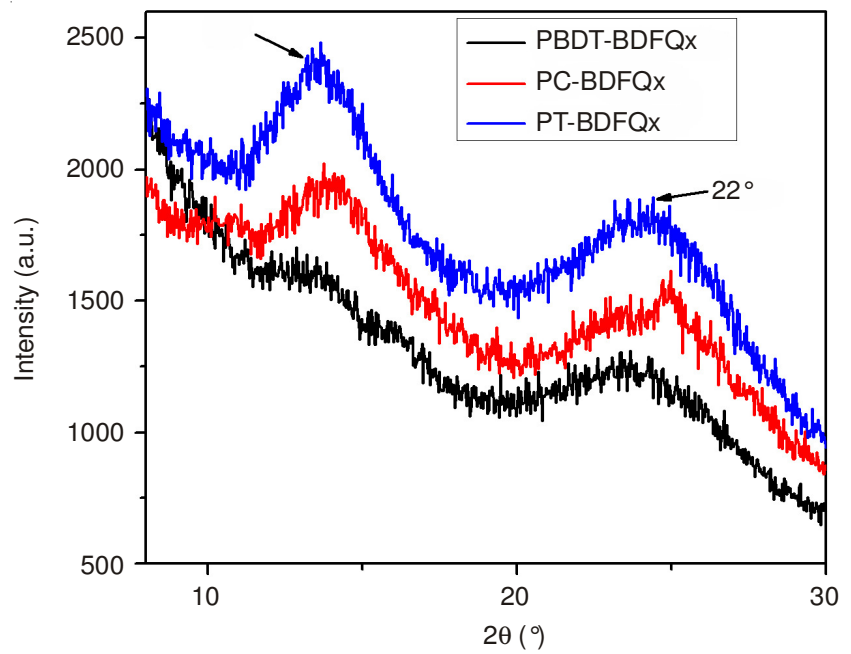

Fig. 4. XRD diffractograms of the film samples of the polymers

Electrochemical properties and electronic energy levels: The highest occupied molecular orbital (HOMO) and lowest unoccupied molecular orbital (LUMO) energy levels of the conjugated polymers are important parameters in the design of optoelectronic devices and they can be estimated from the onset oxidation and reduction potentials ${ }^{23}$. As the redox potential of $\mathrm{Fc} / \mathrm{Fc}^{+}$is considered to have an absolute energy level of $-4.8 \mathrm{eV}$ relative to vacuum, the HOMO/LUMO energy levels of the polymers are calculated using the equation $^{24,25}$ : HOMO/LUMO $=-\left[\mathrm{E}^{\text {onset }}+4.8\right] \mathrm{eV}$ and electrochemical band gaps of these polymers are estimated according to the equation: $\mathrm{E}_{\mathrm{g}}{ }^{\mathrm{ec}}=\mathrm{E}_{\mathrm{ox}}{ }^{\text {onset }}-\mathrm{E}_{\mathrm{red}}{ }^{\text {onset }}$. Cyclic voltammograms (CV) of these macromolecules are shown in Fig. 5 and Table2. In the scanning of the positive potential, except polymer PBDT-BDFQx, the other two polymers emerged oxidation initial potential ( $\left.\mathrm{E}_{\text {ox }}{ }^{\text {onset }}\right)$ at $0.97 \mathrm{~V}(\mathrm{PC}-\mathrm{BDFQx})$ and $0.76 \mathrm{~V}$ (PT-BDFQx), respectively. The $\mathrm{E}_{\mathrm{ox}}{ }^{\text {onset }}$ is decided by the electric units of polymer and carbazole, thiophene and BDT for electronic ability each are not identical. For the negative potential, three polymers started reduction potential ( $\mathrm{E}_{\text {red }}{ }^{\text {onset }}$ ) at $-1.40 \mathrm{~V}$ (PC-BDFQx), -1.27 V(PT-BDFQx) and $-1.20 \mathrm{~V}$ (PBDT-BDFQx), respectively. Three datas were similar. This is because the polymer $\mathrm{E}_{\mathrm{red}}{ }^{\text {onset }}$ is decided by the power shortage units in the polymer. By formula, the HOMO energy level of PC-BDFQx and PT-BDFQx are calculated to be -5.77 and $-5.56 \mathrm{eV}$, while the LUMO energy level of PC-BDFQx, PTBDFQx and PBDT-BDFQx are -3.40, -3.60 and $-3.53 \mathrm{eV}$, respectively. The energy gap of polymers can be calculated to be $2.37 \mathrm{eV}$ (PC-BDFQx) and $1.96 \mathrm{eV}$ (PT-BDFQx), the results are closed to the optical methods. According to the optical energy gap, available the HOMO energy level of PBDTBDFQx is $-5.50 \mathrm{eV}$. Compared with literature reports of similar structure with quinoxaline unit for donor material (LUMO = about $-3.40 \mathrm{eV})$, the three polymers have lower LUMO energy level $(-3.40-3.60 \mathrm{eV})$ and HOMO energy level is reduced to -5.50-5.77 eV, consistent with our design intent.
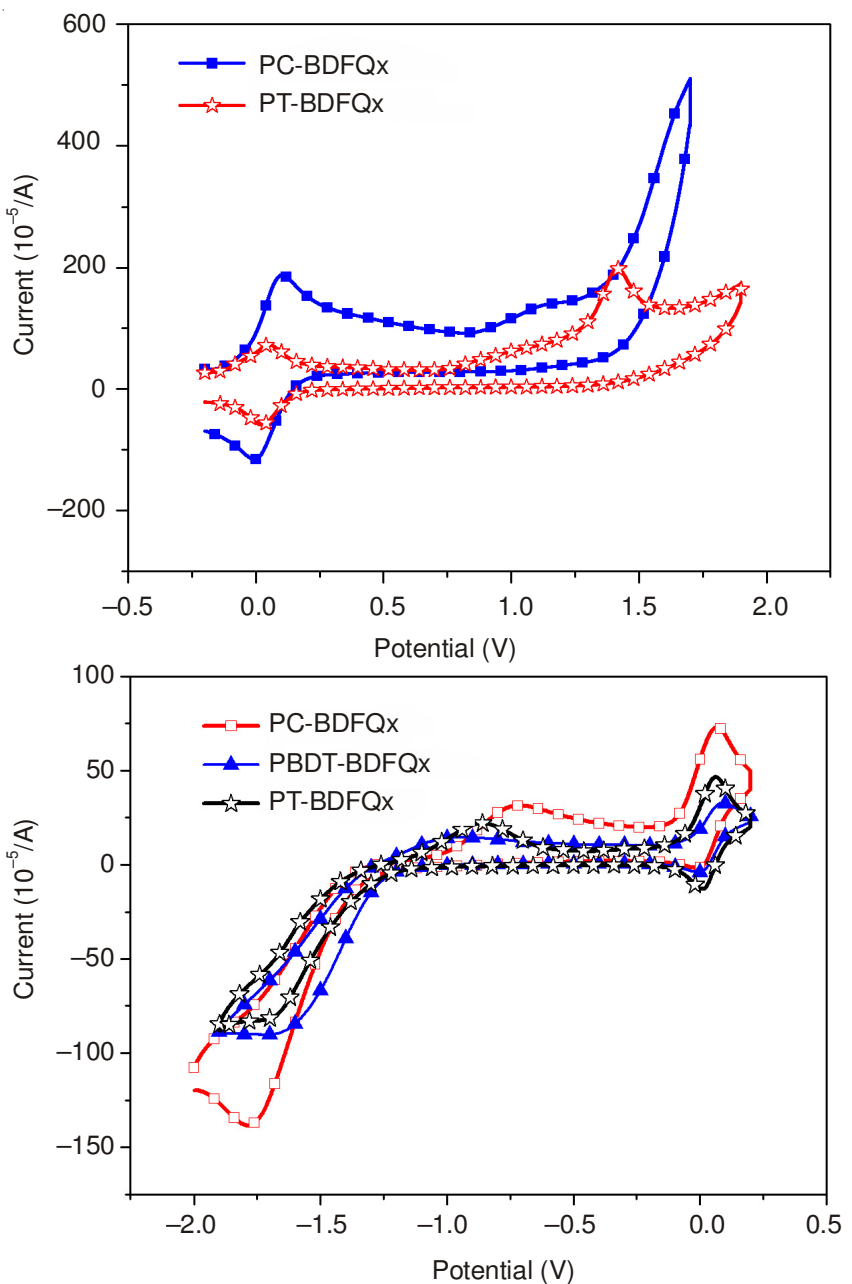

Fig. 5. Cyclic voltammograms of polymer films on a platinum electrode in $0.1 \mathrm{~mol} \mathrm{~L}^{-1} \mathrm{Bu}_{4} \mathrm{NPF}_{6}$ acetonitrile solutions at a scan rate of 100 $\mathrm{mV} \mathrm{s}^{-1}$

Photovoltaic properties: To investigate the photovoltaic properties of these copolymers, the BHJ polymer solar cells with a sandwich structure of ITO/ PEDOT: PSS (25 nm)/ polymer: $\mathrm{PC}_{60} \mathrm{BM}$ (m: n, w/w, $\left.75 \mathrm{~nm}\right) / \mathrm{LiF}(0.7 \mathrm{~nm}) / \mathrm{Al}(100$ $\mathrm{nm}$ ) were fabricated. Each group of devices are made annealing treatment at $80^{\circ} \mathrm{C}$. The $\mathrm{J}-\mathrm{V}$ characteristics of the cells using the three macromolecules as donor measured under the illumination of AM $1.5 \mathrm{G}\left(100 \mathrm{~mW} / \mathrm{cm}^{2}\right)$ from a solar simulator are shown in Fig. 6 and the photovoltaic performances of these 
copolymers-based cells are summarized in Table-3. We use polymer PBDT-BDFQx which has the best absorption and PCBM in different mass ratios to prepare polymer solar cell devices, aimed to the ratio's influence to the device performance and the test results shown in Tables 1-3. Results can be seen from the data: when the quality ratio of $1: 3$, the device has the highest efficiency of $0.90 \%$; when the ratio of $1: 2$, the device has the highest open circuit voltage of $0.80 \mathrm{~V}$; the cause of the high efficiency for ratio of $1: 3$ due to the improvement of short circuit current; the open circuit voltage of three devices is above $0.60 \mathrm{~V}$, but the fill factor and short circuit current are low, which is a key factor of device low efficiency.
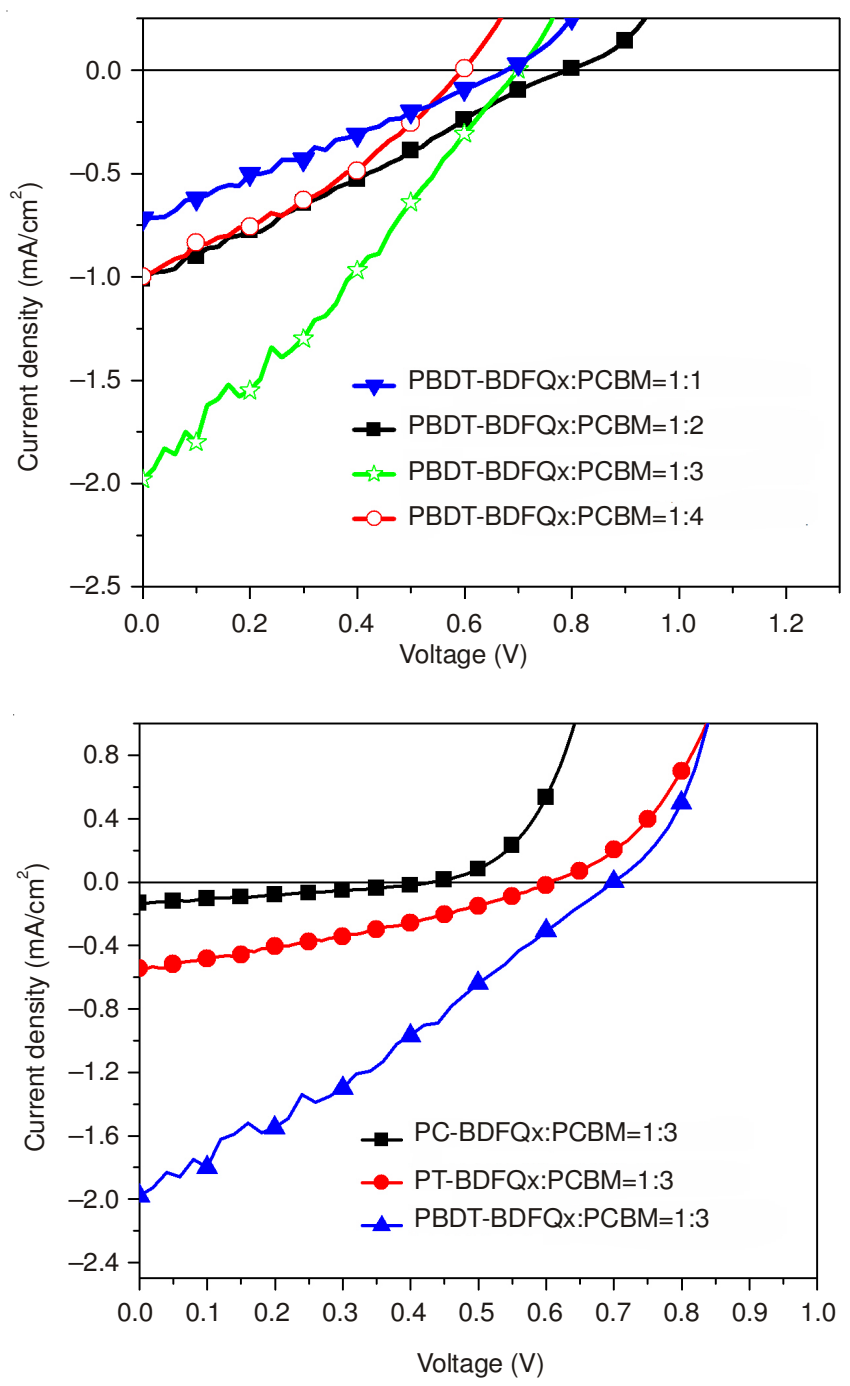

Fig. 6. J-V curves of the polymer solar cells based on polymer: $\mathrm{PC}_{61} \mathrm{BM}$ under the illumination of AM 1.5, $100 \mathrm{~mW} \mathrm{~cm}$
In addition, we prepare solar cell devices by making use of three polymer materials and PCBM in mass ratio of 1:3, observed the performance of different material cells and the test results shown in Tables 1-3. Theoretical calculation of the open circuit voltage through the HOMO and LUMO energy level of the three kinds of polymers were above $1 \mathrm{~V}$, but the autual open circuit voltage of three polymers are lower than theoretical data, that is because the open circuit voltage is also affected by the film morphology. So we made blend membrane with the mass ratio of 1:3 of polymer PT-BDFQx with PCBM and morphology analysis of AFM (Fig. 7). Result shows that the morphology of this kind of thin film is not ideal and the RMS is up to $5.02 \mathrm{~nm}$, which is not conductive to the contact interface. This also leads to short circuit current and fill factor are not too high, which is an important reason for the device low efficiency. But the process of making film can be adjusted to achieve a better state for the interface to improve efficiency, so that, through the subsequent efforts to obtain high efficiency promising device is expected.
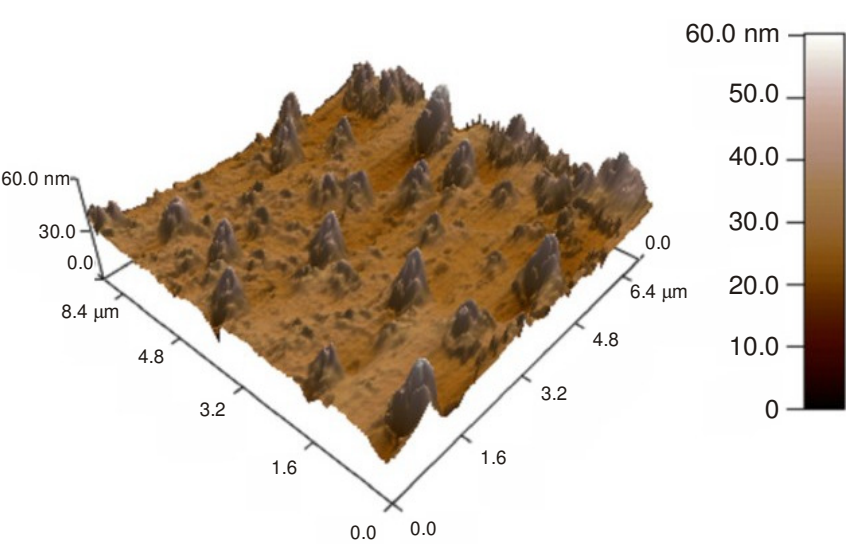

Fig. 7. AFM image of PT-BDFQx/PCBM $=1: 3$ blend film $(\mathrm{RMS}=5.02 \mathrm{n})$

\section{Conclusion}

In summary, a series of alternating copolymers (PTBDFQx, PC-BDFQx and PBDT-BDFQx) have been synthesized bearing novel planar bis(9,9-di(2-ethylhexyl)-9Hfluoren-2-yl)quinoxaline (BDFQx) as acceptor unit, using benzo[1,2- $\left.b: 4,5-b^{\prime}\right]$-dithiophene (BDT), thiophene (T) and carbazole (C) as donor units. All polymers have deep HOMO energy levels below $-5.5 \mathrm{eV}$, but the PCE data are not ideal. The reason may be due to the poor morphology of polymers and require more study. By comparision under the same conditions, these copolymers containing BDT units exhibited higher PCE and $\mathrm{J}_{\mathrm{sc}}$ than the other copolymers. A maximum PCE of $0.9 \%$ and a highest $\mathrm{J}_{\mathrm{sc}}$ of $4.38 \mathrm{~mA} / \mathrm{cm}^{2}$ were obtained for PBDT-BDFQx. All these results demonstrate that BDFQx

TABLE-3

PHOTOVOLTAIC PERFORMANCE OF THE POLYMER SOLAR CELLS BASED ON THE POLYMERS/PCBM BLENDS

\begin{tabular}{lcccc}
\hline \multicolumn{1}{c}{ Active layer } & $\mathrm{V}_{\mathrm{oc}}(\mathrm{V})$ & $\mathrm{J}_{\mathrm{sc}}\left(\mathrm{mA} / \mathrm{cm}^{2}\right)$ & $\mathrm{FF}$ & PCE $(\%)$ \\
\hline PBDT-BDFQx:PCBM=1:3 & 0.70 & 4.38 & 0.29 & 0.90 \\
PBDT-BDFQx:PCBM=1:4 & 0.60 & 2.21 & 0.33 & 0.43 \\
PBDT-BDFQx:PCBM=1:2 & 0.76 & 1.75 & 0.27 & 0.36 \\
PBDT-BDFQx:PCBM=1:1 & 0.68 & 1.59 & 0.27 & 0.29 \\
PT-BDFQx:PCBM=1:3 & 0.61 & 0.77 & 0.35 & 0.17 \\
PC-BDFQx:PCBM=1:3 & 0.43 & 0.29 & 0.30 & 0.04 \\
\hline
\end{tabular}


is a promising building block as acceptor moiety for construction of high performance polymer solar cell.

\section{ACKNOWLEDGEMENTS}

The authors gratefully thank the financial support from the National Natural Science Foundation of China (Project grant No. 50803040 and 20872103) and the Open Project Program of Key Laboratory of Environmentally Friendly Chemistry and Applications of Ministry of Education, China (No. 10HJYH02). Thanks are also due to Analytical \& Testing Center of Sichuan University for providing measurements of NMR and UV-visible for the intermediates and objective compounds.

\section{REFERENCES}

1. (a) M. Gratzel, Inorg. Chem., 44, 6841 (2005); (b) J.R. Durrant, S.A Haque and E. Palomares, Chem. Commun., 3279 (2006); (c) S. Gunes, H. Neugebauer and N.S. Sariciftci, Chem. Rev., 107, 1324 (2007); (d) E. Bundgaard and F.C. Krebs, Sol. Energy Mater. Sol. Cells, 91, 954 (2007); (e) B.C. Thompson and J.M. Frechet, J. Angew. Chem. Int. Ed., 47, 58 (2008); (f) A. Mishra, M.K.R. Fischer and P. Bäuerle, Angew. Chem. Int. Ed., 48, 2474 (2009).

2. C.W. Tang, Appl. Phys. Lett., 48, 183 (1986).

3. Z. He, C. Zhong, S. Su, M. Xu, H. Wu and Y. Cao, Nat. Photonics, 6, 591 (2012).

4. L. Dou, J. You, J. Yang, C.C. Chen, Y. He, S. Murase, T. Moriarty, K. Emery, G. Li and Y. Yang, Nat. Photonics, 6, 180 (2012).

5. L. Dou, W.H. Chang, J. Gao, C.C. Chen and J. You, Y. Yang, Adv. Mater., 25, 825 (2012)

6. E. Wang, L. Hou, Z. Wang, Z. Ma, S. Hellström, W. Zhuang, F. Zhang, O. Inganäs and M.R. Andersson, Macromolecules, 44, 2067 (2011).

7. J.E. Carlé, M. Jørgensen, M. Manceau, M. Helgesen, O. Hagemann, R. Søndergaard and F.C. Krebs, Sol. Energy Mater. Sol. Cells, 95, 3222 (2011).
8. Y. Zou, Z. Guan, Z. Zhang, Y. Huang, N. Wang, Z.Y. Lu, Q. Jiang, J. Yu, Y. Liu and X. Pu, J. Mater. Sci., 47, 5535 (2012).

9. M.C. Scharber, D. Mu“hlbacher, M. Koppe, P. Denk, C. Waldauf, A.J. Heeger and C.J. Brabec, Adv. Mater., 18, 789 (2006).

10. E. Wang, L. Hou, Z. Wang, S. Hellström, F. Zhang, O. Inganäs and M.R. Andersson, Adv. Mater., 22, 5240 (2010).

11. W.-H. Lee, S.K. Son, K. Kim, S.K. Lee, W.S. Shin, S.-J. Moon and I.-N. Kang, Macromolecules, 45, 1303 (2012).

12. M.H. Lai, J.H. Tsai, C.C. Chueh, C.F. Wang and W.C. Chen, Macromol. Chem. Phys., 211, 2017 (2010).

13. M. Ranger, D. Rondeau and M. Leclerc, Macromolecules, 30, 7686 (1997).

14. D.J. Hong, E. Lee, H. Jeong, J.K. Lee, W.C. Zin, T.D. Nguyen, S.C. Glotzer and M. Lee, Angew. Chem. Int. Ed., 48, 1664 (2009).

15. T. Ishiyama, M. Murata and N. Miyaura, J. Org. Chem., 60, 7508 (1995).

16. J. Hou, Z.A. Tan, Y. Yan, Y. He, C. Yang and Y. Li, J. Am. Chem. Soc., 128, 4911 (2006)

17. Y. Nie, B. Zhao, P. Tang, P. Jiang, Z. Tian, P. Shen and S. Tan, J. Polym. Sci. A: Polym. Chem., 49, 3604 (2011).

18. Y.P. Yu, L.M. Sun and Q. Zhang, J. Shanghai Jiaotong Univ. (Sci.), 10, 1662 (2007).

19. M. Helgesen, T.J. Sorensen, M. Manceau and F.C. Krebs, Polym. Chem., 2, 1355 (2011).

20. Z. Qi, B. Wei, Y. Sun, X. Wang, F. Kang, M. Hong and L. Tang, Polym. Bull., 66, 905 (2011).

21. Y. Lee, Y.M. Nam and W.H. Jo, J. Mater. Chem., 21, 8583 (2011).

22. R. Mondal, N. Miyaki, H.A. Becerril, J.E. Norton, J. Parmer, A.C. Mayer, M.L. Tang, J.-L. Brédas, M.D. McGehee and Z. Bao, Chem. Mater., 21, 3618 (2009).

23. Y.F. Li, Y. Cao, J. Gao, D.L. Wang, G. Yu and A.J. Heeger, Synth. Met., 99, 243 (1999).

24. J. Pommerehne, H. Vestweber, W. Guss, R.F. Mahrt, H. Bässler, M. Porsch and J. Daub, Adv. Mater., 7, 551 (1995).

25. C. Hu, Y. Fu, S. Li, Z. Xie and Q. Zhang, Polym. Chem., 3, 2949 (2012). 